\title{
Notes
}

CHROM. 3326

\section{Gas chromatographic separation of carbonyl fluoride and carbon dioxide}

The simultaneous quantitative evaluation of $\mathrm{CF}_{2} \mathrm{O}-\mathrm{CO}_{2}$ mixtures is important in numerous kinetic studies including the oxidation of $\mathrm{C}_{2} \mathrm{~F}_{4}$ and the pyrolysis of $\mathrm{CF}_{2} \mathrm{O}$. The gas chromatographic analysis of $\mathrm{CF}_{2} \mathrm{O}$ has been reported by CoRDEs ${ }^{1}$ and BANKS, HASZELDINE AND SUTCLIFFE2. Unfortunately neither of the columns used can separate $\mathrm{CF}_{2} \mathrm{O}-\mathrm{CO}_{2}$ mixtures. HEICKLEN and co-workers ${ }^{3,4}$ have measured $\mathrm{CF}_{2} \mathrm{O}$ in gas mixtures by quantitatively converting the $\mathrm{CF}_{2} \mathrm{O}$ to $\mathrm{CO}_{2}$ on silica gel columns and measuring the $\mathrm{CO}_{2}$ effluent. The purpose of this paper is to describe a gas chromatographic technique for the simultaneous quantitative determination of both $\mathrm{CF}_{2} \mathrm{O}$ and $\mathrm{CO}_{2}$.

\section{Experimental}

Apparatus. An Aerograph model No. 202-B gas chromatograph equipped with a thermal conductivity cell was used for this study. Mixtures were introduced into the gas chromatograph through a gas sampling valve used in conjunction with a $2 \mathrm{ml}$ sample volume. Peak areas were measured with a Disc Integrator (5000 counts per min) which was attached to a Sargent ro in. recorder.
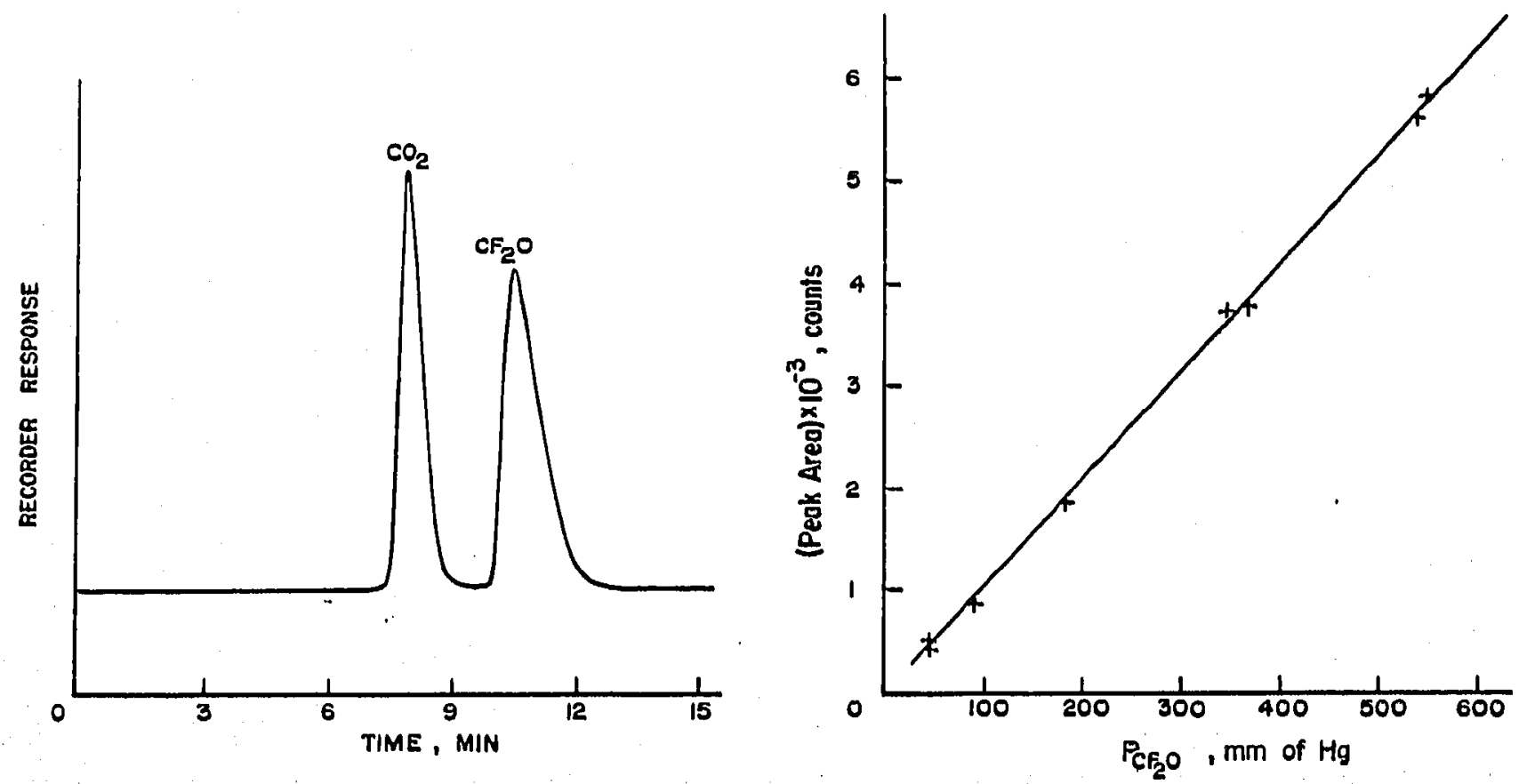

Fig. I. Typical chromatogram of $\mathrm{CO}_{2}-\mathrm{CF}_{2} \mathrm{O}$ mixture.

Fig. 2. $\mathrm{CF}_{2} \mathrm{O}$ peak area as a function of sample pressure. 
Column materials and preparation. A $6 \mathrm{ft}$. composite column consisting of $2 \mathrm{ft}$. of 50/80 mesh Porapak (Waters Associate, Inc.) type T followed by $4 \mathrm{ft}$. of 50/80 mesh Porapals type $\mathrm{N}$ was used for the analysis. The column was packed in $1 / 4$ in. O.D. Type 316 stainless steel tubing. Before final installation in the chromatograph, the column was heated to $200^{\circ}$ and purged with helium (6o ml/min) for $2 \mathrm{~h}$. Prior to each series of runs the column was conditioned by passing three 250 torr samples of $\mathrm{CF}_{2} \mathrm{O}$ through it.

Results and discussion

A typical chromatogram indicating the separation of $\mathrm{CF}_{2} \mathrm{O}$ and $\mathrm{CO}_{2}$ as obtained with the column described above is given in Fig. I. The operating conditions. corresponding to the results given in Fig. I are: column temperature $23^{\circ}$; helium flow rate $60 \mathrm{ml} / \mathrm{min}$. A plot of $\mathrm{CF}_{2} \mathrm{O}$ peak area as a function of $\mathrm{CF}_{2} \mathrm{O}$ pressure in the $2 \mathrm{ml}$ sample volume is shown in Fig. 2. These results indicate that the detector response is linear over an eleven fold increase in $\mathrm{CF}_{2} \mathrm{O}$ concentration. The curve given in Fig. 2 approaches the origin as the sample pressure is decreased. This behavior indicated that $\mathrm{CF}_{2} \mathrm{O}$ absorption on this column is essentially nonexistent.

\section{Acknowledgement}

This research was sponsored by the Air Force Office of Scientific Research, Office of Aerospace Research, United States Air Force, under Grant number AFAFOSR-II44-66.

Fluid Dynamics Laboratory, Department of Mechanical Engineering, University of Michigan, George A. Drennan Ann Arbor, Mich. 48104 (U.S.A.)

I I. L. Cordrs, Chem. Ind. (London), (I966) 340.

2 R. E. Banis, R. N. Haszeldine aNd H. Sutcliffe, J. Chem. Soc., (1964) 4066.

3 J. Hetcklen, V. KNIGH T and S. Greene, J. Chem. Phys., 42 (I965) 221.

4 D. Saunders and J. Heicislen, J. Am. Chem. Soc., 87 (ig65) 2088.

Received November I3th, I967

J. Chromatog., 34 (1968) $77-78$

CHROM. 3347

\section{Synthetic diamond-A solid adsorbent for corrosive gases}

A satisfactory chromatographic system for the analysis of corrosive halogen gases has proven to be an illusive objective. Recent publications ${ }^{1-5}$ in this area are indicative of continuing difficulties encountered in the separation of these reactive materials. Primarily chromatographic separations have been concerned with inorganic penta- and hexa-fluorides, chlorine trifluoride and anhydrous hydrofluoric acid. No substrate or support has been recommended for gaseous mixtures containing 